\title{
Market Orientation and Organizational Performance in Tourism and Travel Industry
}

\author{
Dr. Yogesh Upadhyay ${ }^{1}$, Ruturaj Baber ${ }^{2}$ \\ ${ }^{1}$ Professor and Pro-Vice Chancellor, ITM University, Gwalior \\ ${ }^{2}$ Asst. Professor, Aditya College, Gwalior
}

\begin{abstract}
This study explores market orientation in the Tourism and Travel companies. Authors hypothesized a positive relationship between market orientation and four organizational factors, including professional commitment, professional education, and professional ethics of the senior management team, and organizational entrepreneurship, and also the three environmental factors, including perceptions of two states of competition and the demand. The study also examines the relationship between market orientation and Organizational Performance. Data from top Tourism and Travel Companies was collected and was used to empirically test the hypothesized relationships.
\end{abstract}

\section{Introduction}

Market Orientation has been defined as "organization wide generation of market intelligence, dissemination of market intelligence, Dissemination of market information across the departments, and organization wide responsiveness to market intelligence." by Kohli and Jaworski (1990). The advantages of an organization for being market orientated are discussed by various scholars in research papers, books articles etc (Webster, 1988; Kotler, 1988, Payne, 1988). High level of market orientation has been related with higher business performance (Kohlo and Jaworski, 1990; Narver and Slater, 1990; Opeda, 2011; Sussan and Johnson, 1997; Mahmoud 2011). Moreover, in simple words market orientation is said to be main construct behind successful current marketing management and strategies.

Various scholars have come up with empirical work on the topic of market orientation. Researchers in past have focused on replicating antecedents and consequences of market orientation, and towards development of an applicable measure of construct to test its effect on organizational performance ((Jaworski and Kohli, 1993; Kohli, Jaworski, and Kumar, 1993; Narver and Slater, 1990; Siguaw, Brown, and Widing, 1994; Slater and Narver, 1994). Earlier researches, however have several limitations. The studies used Strategic business units (SBU), banking sector, manufacturing sector, but tourism and travel sector has been overlooked. These have provided precious insights. The stoutness of marketing orientation models should be studied using other industry type, specifically tourism and travel industry. There is also need of identifying the role of additional influences on market orientation within organizations (Hambrick, 1987; Jaworski and Kohli, 1993; Siguaw, Brown, and Widing, 1994). Kohli, Jaworski, and Kumar, 1993; Narver and Slater, 1990 tried to expand valid measures of market orientation with limited results. Narver and Slater's (1990) measure of market orientation was criticized for its narrow focus and inclusion of items that did not reflect certain activities and behaviors representing market orientation (Kohli, Jaworski and Kumar, 1993). Kohli, Jaworski and Kumar (1993) recommended extra attention to be paid towards market orientation. They also suggested application of the concept of market orientation to service industry.

As many practitioners have testified, that the present environment confronting service sector is challenging. There is an ever increasing demand for services (Kotler and Andreason, 1991). Although various precise propositions have been presented to address these challenges, various authors have called in for a wider approach, including a model of market orientation in Tourism and travel industry. Various attempts have been made by various authors focusing towards research in tourism industry related with market orientation (Qu et al, 2005: Bigne et al, 2005).

This study is guided by the attempts that have been made earlier by researchers and critiques. The results of the study will contribute to our overall knowledge of market orientation in tourism and travel industry by extending the work of earlier studies done by researchers (e.g. Kohli and Jaworski, 1990: Narver and Slater, 1993: Kohli, Jaworski and Kumar, 1993: Wood and Bhuian, 1993). Specially, the research reported here is focused towards: 
1) Development of model describing a relationship between market orientation, its antecedents and the consequent 'Organizational Performance'.

2) Testing of the models by empirical examination of eight specific hypotheses concerning with the antecedents and consequents of market orientation.

3) Presenting of the results and implications for managers and researchers in quest of prescriptive advices for improvement organizational performance.

The focus is on tourism and travel industry, addressing the call for more research in this area.

\section{Background: The Model}

In present era, academicians, researchers and practitioners have increased their focus on market orientation and the factors that produce this orientation in the organizations. Narver and Slater (1990) and Kohli and Jaworski (1990) noted that market orientation has always of interest of individuals which they held responsible for attaining organizational performance. Figure.1 displays the hypothesized model of the current study.

Market Orientation

Market orientation has been recognized as vital success factors in organizations of present day. There are two prominent concepts of market orientation that were given by Jaworski and Kohli (1990) and Narvar and Slater (1990). While Jaworski and Kohli (1990) considered market orientation as the implementation of the Marketing concept, Narver and Slater (1990) considered it as an organizational culture. It is simply earning profit by creating opportunities to more effectively satisfy our customers' needs within the constraints of our resource and skill limitations", (Payne A. 1988).

Kohli and Jaworski (1990) defined market orientation as "the organization-wide generation of market intelligence, dissemination of the intelligence across departments and organization-wide responsiveness to it". Deshpande and Farley (1998) defined market orientation as "the set of cross-functional processes and activities directed at creating and satisfying customers through continuous needs-assessment". Market orientation is defined as the organization culture (i.e., culture and climate, Deshpande and Webster 1989) that effectively and efficiently creates the necessary behaviors for the creation of superior value for buyers and, thus, continuous superior performance for the business (Aaker 1988; Kohli and Jaworski 1990; Kotler 1984; 1982; Shapiro 1988; Webster 1988). Kohli and Jaworski (1990) elucidated briefly the market orientation construct. They explained market orientation as a marketing concept. The following elements were given in the construct by them; (1) Intelligence Generation: market orientation starts from intelligence generation. It was referred as collection of intelligence through various formal and informal means. And they also quoted that generation of intelligence is not exclusive function of the marketing department. It can be collected by each any every employee of the organization and both frontend and back end. The generated intelligence can be related to customer, competitors and changes in technology etc, (2) Intelligence Dissemination: authors related intelligence dissemination with the flow of information within the organization. It is all about the communicating and educating the fellow managers in other functionalities within the organization (Levitt, 1969). Authors expressed that there should be formal procedure for intelligence dissemination. The horizontal communication of intelligence is also a form of intelligence dissemination within an organization, and (3) Responsiveness: the final element of market orientation is responsiveness to market intelligence. Authors stated that there should be proper responsive to the intelligence which have been received by the managers/employees of the organization. An organization cannot accomplish its objectives until it is responsive to the generated intelligence. Authors also stated that all departments should respond to the information received by them. The key Elements of market orientation are outlined in Figure. 2

Antecedents to Market Orientation

Various researchers in their studies have explored probable antecedents to market orientation (e.g. Kohli and Jaworski, 1990; Narver and Slater, 1990; Woods and Bhuian, 1993). As displayed in Figure. 1, this study proposes that the degree of market orientation of an organization is depending upon seven main antecedents that are: (1) Professional commitment of senior management team, (2) Professional Education of Senior Management Team, (3) Professional Ethics of Senior Management Team, (4) Operational Entrepreneurship, (5) Perception of Presence and Intensity of Competition, (6) Perception of Competition as a threat, and (7) Perception of Demand as under or over the capacity to serve. 


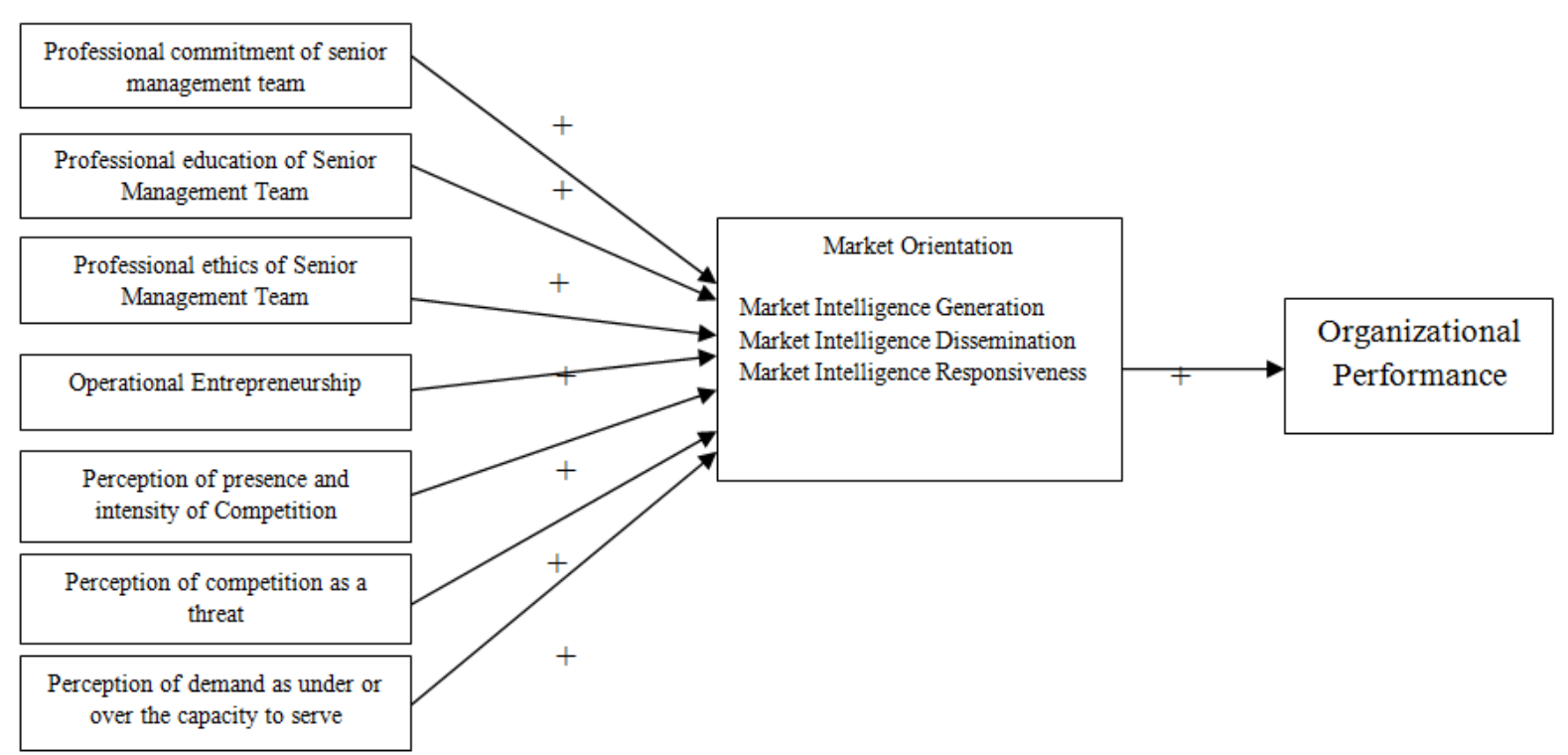

Figure 1. Antecedents and consequents of Market Orientation: Hypothesized model.

The degree of market orientation directly influences the organizational performance. Discussed below are the seven main antecedents of market orientation.

Professional commitment of senior management team: it is key aspect of professionalism (Bartol, 1979; Carbone, 1990; Woods and Bhuian, 1993).It refers to an individual's commitment with career and desire to remain in a particular profession, if provided with opportunities to change professions. Several scholars have suggested that that professionalism of senior management teams is a one of the key factors towards development of a customer orientation and consequently attaining immense organizational success (Drucker, 1989; Kotler and Andreason, 1991; Harmancioglu et al, 2010). In fact, in effort to ensure regular quality service to customers, senior management of numerous organizations are giving an effort to enhance their professionalism through participating in a broad range of management training activities (Byrne, 1990). A precise assessment of the construct suggests that professionalism of senior management teams possibly could be related to market orientation (Unterman and Davis, 1984; Harmancioglu et al, 2010). A high level of professional commitment is seen in senior managers and they also have view that 'their work is their career rather than just a job'. Such kind of dedication to career and aspirations reinforce long-term professional goals (e.g., consistently providing quality service to the customers). Consequently, this long-term orientation is likely to influence the value senior managers' place on information about customers who are the essence of a market orientation.

Professional education of the senior management team: it is another dimension of professionalism that seems to play important role in market orientation. If refers to the belief that continual professional education is important for high quality management (Hambrick et al, 1989; Hampton and Hampton, 2004). Senior managers of operations who are strongly identified by their profession often tend to emphasize their continuous skills development for themselves as well as for other members of the management team. Different development programs of associated professional societies are utilized by them (Wood and Bhuian, 1993), providing different educational opportunities to their members, which include information dissemination, researches, conferences and seminars which again open up a portal through which exchange of ideas among professionals can be done. These activities aim towards improvement of the knowledge and skills of members to ensure consistent, highquality service to their customers. As suggested above, improved services to customers require information about customers, which is the essential for market orientation.

Professional ethics of the senior management team: It is the third dimension of professionalism. It refers to responsibility felt by the senior managers through which they avoid personal reasons which endanger their objective of dedication towards rendering high quality services to customers and also doing it in a right manner (Bartol, 1979; Carbone, 1990). While facing a conflict between self interest and customer interest senior management strengthened with service ethics have deep concern to serve their customers using their profession. Consequently, managers are driven by a high sense of professional ethics leading them to yield their self-interest to customer's interests when conflicts exist. Thus, managers with strong professional ethics are dedicated to serve customers with high service quality. Once again, to serve customers with higher service quality they would be needing information and this resulting in market orientation (Woods and Bhuian, 1993; Singh and Kumar, 2011; Guenzi and Troilo, 2007). 
All of the three dimensions have a common objective; serving of organization's customers. And to serve customers in more satisfying manner, gathering, dissemination and responsiveness to the information is required of customers. This sets direction of an organization towards becoming market orientated.

Organizational entrepreneurship: entrepreneurship has been recognized with a leading organizational personality (Shapiro, 1975). Organizational entrepreneurship is an organization's willingness to support and nurture creativity, flexibility and to take calculated risks (Quince, 2003; Roskos and Klandt, 2007; Liu et al, 2002). Organizational entrepreneurship is the willingness of organization for renewal of efforts towards pursuit of new ventures and opportunities (Burgleman, 1984). Organizational entrepreneurship refers to the organizational process of risk taking, innovativeness, and proactiveness (Covin\&Slevin, 1991; Morris \& Paul, 1987; Liu, Dubinsky, and Shi, 2000). Risk taking is making reasonable in the times of uncertainty. Innovativeness is introduction of new products and services in new markets. Whereas, proactiveness is basically about finding new methods for achievement of organizational objectives. In recent times, organizational entrepreneurship moreover associated with taking constructive risks, more focus on research and development, giving importance to growth over stability and introduction of new products at a rapid pace in market (Woods and Bhuian, 2000).

High level of organizational entrepreneurship and market orientation represent responses towards increasingly complex and turbulent environments (Drucker, 1980, 1985; Wood and Bhuian, 1993, 2000; Grey and Greenly, 1999). In this study we've hypothesized a relationship between entrepreneurship orientation and market orientation.

Perception of Presence and intensity of competition: it encourages organizations to look out for information about those entities which are affected by competition. It supports the view that that organizational success and ultimate survival will come to those organizations that best understand competition which affects them (Kotler and Andreasen, 1991; Steinberg, 1987). The external environment in which an organization operates is complex and ever evolving. Every organization is competing for survival, raw material, customers and their loyalty. Each and every organization is aware about the presence of competition and its intensity. Those organizations which seek after the competition collect accurate information from customers for the purpose of evaluation and also use such kind of information for their own benefit (Narver and Slater, 1994; Woods and Bhuian, 1993, 2000; Lewrick et al, 2011, Armstrong and Collopy, 1996).

Perception of competition as a threat: it is basically evaluation of competition and what damage competition can do to our organization. It leads an organization to evaluate competitors and also to attend the customers (Schwartz, 1989). It is about identification of threat from competition which drives an organization to look their customers need and requirements thereby enhancing the organizational performance (Woods and Bhuian, 1993, 2000; Wang et al, 2011). An organization is more inclined to adopt market orientation when it perceives competition as a threat.

Perception of demand as under or over the capacity to serve:it influences the organizations capacity to search information. It is a situation where the present demand for the organization's goods/services is below the desired demand level; demand over the organization's capacity to serve is a situation where the current demand for the organization's goods/services is above the desired demand level or, more particularly, above the level that can be served (Woods and Bhuian, 1993, 2000; Zhou et al, 2009). Theoretically, organizations seek out for information on customers and adjust their market offerings made. This is done in order to improve the current situation faced by the organization.

\section{Market orientation and organizational performance}

Market orientation has been linked with organizational performance. Various scholars have stated that higher level of market orientation results in higher organizational performance. A positive relationship had been established between market orientation and organizational performance in the past (Narver and Slater, 1990; Kohli and Jaworski, 1990, Han et al 1996; Bunić, 2007; Opeda, 2011). Various studies and researches done in the past show that adaptation of marketing concepts and principles and use of the research in an organization have resulted in greater organizational performance (Kotler 1984; Levitt, 1969; Webster, 1988; Wood and Bhuian, 1993, 2000). The following hypotheses formally state the linkages shown in figure. 1

$\mathrm{H}_{0} 1$ : Market orientation is not positively related to the professional commitment of the senior management team.

$\mathrm{H}_{0} 2$ : Market orientation is not positively related to the professional education of the senior management team.

$\mathrm{H}_{0} 3$ : Market orientation is not positively related to the professional ethics of the senior management team.

$\mathrm{H}_{0} 4$ : Market orientation is not positively related to organizational entrepreneurship.

$\mathrm{H}_{0}$ 5: Market orientation is not positively related to the perception of presence and intensity of competition.

$\mathrm{H}_{0} 6$ : Market orientation is not positively related to perception of competition as a threat.

$\mathrm{H}_{0}$ 7: Market orientation is not positively related to the perception of demand faced by the organization as under or over the capacity to serve. 
$\mathrm{H}_{0} 8$ : Organizational performance is not positively related to market orientation.

In the following section data collection techniques and scale development activities are described which are used to test hypotheses.

Scale development

\section{Method}

Till now, two studies have tried to create a valid for measure of market orientation in an organization, but both had inadequacies. Kohli, Jaworski and Kumar (1993) reviewed work of Narver and Slater (1990) and summarized their limitations. Kohli, Jaworski and Kumar (1993) also listed the shortcomings of their study and described their scale to be too long to be practical. They also stated that the items in the scale were over specified and not generalized according to needs of various industries. And only modest support was presented in the study to validate market orientation. A more refined scale developed by Woods and Bhuian (2000) based on the study of Kohli, Jaworski and Kumar (1993) and this refined scale is used in the present study.

The scale represents the domain and elements of market orientation as displayed in the figure. 2.

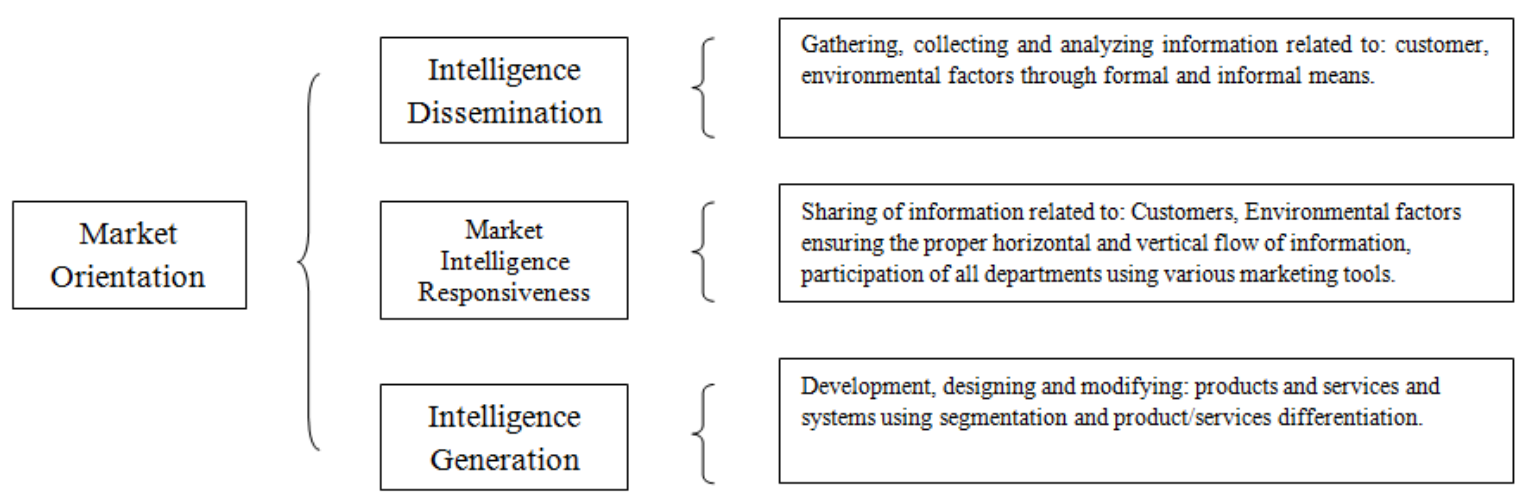

Figure 2. Domain and elements of Market Orientation

Responses were recorded on a 5-point Likert scale (where $1=$ much more time and effort was spent, $3=$ about the same time and effort was spent, and $5=$ much less time and effort was spent .It also includes $1=$ strongly agree, $3=$ neutral, 5=strongly disagree) (Woods and Bhuian, 2000). The scale developed by was Woods and Bhuian (2000) for nonprofit organizations but can be generalized for all kinds of organizations after some after slight alteration. The questionnaire used for the data collection contains 37 questions. Market orientation contains 11 questions. Professional commitment of the senior management team variable, Perception of the presence and intensity of competition and Professional education of the senior management team variable contains 3 questions each. Professional ethics of the senior management team contains 2 questions. Organizational entrepreneurship variable contains 8 questions. Perception of competition as a threat variable contains 2 questions. Perception of demand as under or over the capacity to serve variable contains 1 question. Organizational performance variable contains 4 questions.

\section{Data Collection}

The data was collected through self administrated questionnaires from 100 senior level executives irrespective of their qualification from Central India namely Gwalior, Bhind, Morena, Indore, Bhopal, Dholpur, and Datia. Out of 100 questionnaires filled by the respondents, 71 were returned by the respondents and 60 were considered usable in testing stage. Convenience sampling method was used to collect the data.

\section{Characteristics of Sample}

\begin{tabular}{|c|l|c|}
\hline \multirow{3}{*}{ Gender } & Male & 41 \\
\cline { 2 - 3 } & Female & 19 \\
\cline { 2 - 3 } & Total & 60 \\
\hline \multirow{3}{*}{ Type of Organization } & Private & 59 \\
\cline { 2 - 3 } & Public & 01 \\
\cline { 2 - 3 } & Total & 60 \\
\hline \multirow{3}{*}{ Age Group } & Below 25 years & 15 \\
\cline { 2 - 3 } & $25-35$ years & 25 \\
\cline { 2 - 3 } & 35 and above & 20 \\
\cline { 2 - 3 } & Total & 60 \\
\hline
\end{tabular}




\section{Analysis and Discussions}

Item describing Professional Education "travel agency operator strongly believe in the importance of continuing professional education (e.g., attending seminars, workshops, and conferences on various issues concerning professional development)" was deleted from the questionnaire by the researcher to increase alpha coefficient to 0.614 from 0.592 which is acceptable (Nunnally, 1978; 1988).

Table 1: Factor Analysis of Market Orientation scale

\begin{tabular}{|c|c|c|c|}
\hline Variable & Items & Communalities & $\begin{array}{c}\text { Factor } \\
\text { Loading }\end{array}$ \\
\hline \multirow{4}{*}{$\begin{array}{l}\text { Intelligence } \\
\text { Generation }\end{array}$} & Understanding customer's needs. & .666 & .798 \\
\hline & $\begin{array}{l}\text { Understanding how external environmental factors } \\
\text { Influence customer's needs. }\end{array}$ & .698 & .622 \\
\hline & $\begin{array}{l}\text { Understanding how the marketing programs } \\
\text { Competitors influence customers' expectations } \\
\text { and service preferences. }\end{array}$ & .597 & .664 \\
\hline & $\begin{array}{l}\text { Utilizing as many means as possible to generate } \\
\text { market information. }\end{array}$ & .511 & .577 \\
\hline \multirow{3}{*}{$\begin{array}{l}\text { Intelligence } \\
\text { Dissemination }\end{array}$} & $\begin{array}{l}\text { Ensuring that market information is communicated } \\
\text { to all relevant departments in the organization.* }\end{array}$ & .682 & .352 \\
\hline & $\begin{array}{l}\text { Conducting interdepartmental meetings to discuss } \\
\text { market trends and developments. }\end{array}$ & .547 & .734 \\
\hline & $\begin{array}{l}\text { Disseminating data on customer satisfaction to all } \\
\text { relevant departments. }\end{array}$ & .611 & .683 \\
\hline \multirow{4}{*}{ Responsiveness } & $\begin{array}{l}\text { Developing goods and services based on } \\
\text { information concerning Customer's needs. }\end{array}$ & .511 & .687 \\
\hline & $\begin{array}{l}\text { Developing systems to promote, deliver, and price } \\
\text { your goods and services based on information } \\
\text { concerning customers' needs. }\end{array}$ & .575 & .743 \\
\hline & $\begin{array}{l}\text { Utilizing marketing techniques to develop new } \\
\text { goods and services. }\end{array}$ & .662 & .782 \\
\hline & $\begin{array}{l}\text { Utilizing marketing techniques to develop systems } \\
\text { to promote, deliver, and price goods and services. }\end{array}$ & .621 & .673 \\
\hline
\end{tabular}

*Item Deleted

The dimensionality and reliability of the MO scale were estimated by factor analysis and coefficient alpha. In the factor analysis items exhibited an inability to discriminate among the three dimensions (intelligence generation, dissemination, responsiveness) and resulted in market orientation construct. The fifth item in Intelligence Dissemination: Ensuring that market information is communicated to all relevant departments in the organization was not included in the scale.

Table 2: Reliability Statistics

\begin{tabular}{|c|c|}
\hline $\begin{array}{c}\text { Cronbach's } \\
\text { Alpha }\end{array}$ & $\mathrm{N}$ of Items \\
\hline .617 & 10 \\
\hline
\end{tabular}

Nunnally, (1978) recommended calculation of coefficient alpha (also known as Cronbach alpha) in order to assess the reliability of a multiple-item variable. Churchill and Peter (1984) suggested an accepted level for the alpha coefficient. According to them a value of alpha below 0.60 is undesirable. Nunnally, $(1978 ; 1988)$ indicated that new developed measures can be accepted with an alpha value of 0.60 , otherwise, 0.70 should be the threshold. However, considering the use of these scales for the first time in a new culture, the cut off value for the alpha coefficient was set up for 0.60 for all the scales (self-developed scales). The Alfa Coefficient of the market orientation scale is 0.617 which is acceptable. 
To test the hypotheses stated above, standardized regression analysis (the method of multiple regression) was used. The regression results are displayed in Table 3 and Table 4. The results for the three dimensions of professionalism of senior management team $\left(\mathrm{H}_{0} 1-\mathrm{H}_{0} 3\right)$, organizational entrepreneurship $\left(\mathrm{H}_{0} 4\right)$, perception of competition $\left(\mathrm{H}_{0} 5, \mathrm{H}_{0} 6\right)$, perception regarding state of demand $\left(\mathrm{H}_{0} 7\right)$ are presented. The hypotheses $\mathrm{H}_{0} 1-\mathrm{H}_{0} 7$ are proposed antecedents of market orientation. The last hypotheses, $\mathrm{H}_{0} 8$ composes of organizational performance which in turn is consequent of market orientation (MO). The results displayed in the Table 3 where dependent variable is Market orientation (MO) indicating its relation to professional commitment of the senior management team with significance affect with $p=0.168$ and null hypotheses is not accepted. Whereas professional education of senior management team had no significance affect on Market orientation (MO) with $p=.001$ hence null hypotheses is accepted. Professional ethics, the third dimension of the professionalism of senior management with $p=.058$. It supports the H3. The previous studies like Woods and Bhuian, 2000; Badasch, 1988; Byrne, 1990; Kohli and Jaworski, 1990; Narver and Slater, 1990 have tested and implied the relationship between market orientation and professional commitment of senior management of organizations. But second finding is not consistent with the earlier works of the scholars. No relationship was found between professional education of the senior management and market orientation. The results were found consistent with the works of Woods and Bhuian (2000), where they had the same result against the works of earlier researchers indicating that market orientation of organization being affected by the professional education of the senior management. This inconsistency can be explained by the 'orientation' concept. In simple words 'orientations' evolving according to the changing environment and ever evolving organizations. (Ansoff, 1984; Troye and Wood, 1989). For example, senior management in all industries are nowadays oriented towards cost reduction which is posing as a major problem for an organization. The results of this study also indicate that professional ethics are marginally significant with $p=0.058$. It can be interpreted that in terms of tourism and travel industry, importance of existing and potential customers may not be practical. Various tourism and travel operators may or may not have adequate resources to fulfill the needs of their customers.

The relationship between operational entrepreneurship and market orientation described as $\mathrm{H}_{0} 4$ is accepted through regression analysis. The analysis results shows that the relationship between the two is perfectly significant where $p=.000$, hence null hypotheses is accepted. These findings are not consistent with the earlier empirical and theoretical works of Morris and Paul, 1987; Graham, 1990; Lipp, 1991; Wood and Bhuian, 1993. The result can be interpreted as that the organizations are not active in market area and not performing its entrepreneurial duties like searching new markets, opening new markets, performing R\&D activities etc. The basic function of an entrepreneur is risk taking and expanding its business. It can also be interpreted that the organization is satisfied with the current working area and doesn't wants to explore expand its domain of working, i.e. don't want to take risks.

Table 3: Regression Results Coefficients

\begin{tabular}{|c|c|c|c|c|c|c|}
\hline \multirow{2}{*}{\multicolumn{2}{|c|}{ Model }} & \multicolumn{2}{|c|}{ Unstandardized Coefficients } & Standardized & \multirow[t]{2}{*}{$\mathrm{t}$} & \multirow[t]{2}{*}{ Sig. } \\
\hline & & B & Std. Error & Beta & & \\
\hline \multirow{8}{*}{1} & (Constant) & 15.719 & 2.712 & & 5.797 & .000 \\
\hline & Commitment & .275 & 197 & .147 & 1.397 & .168 \\
\hline & Education & -1.253 & .364 & -.366 & -3.443 & .001 \\
\hline & Ethics & -.664 & .343 & -.213 & -1.937 & .058 \\
\hline & OperEnt & .573 & .111 & .555 & 5.170 & .000 \\
\hline & Perception & -.231 & .199 & -.135 & -1.165 & .250 \\
\hline & Competition & -.082 & .225 & -.041 & -.365 & .717 \\
\hline & Serve & .105 & .279 & .043 & . 377 & .707 \\
\hline
\end{tabular}

a. Dependent Variable: MO

Perception and presence of intensity of competition which constitutes $\mathrm{H}_{0} 5$. Here $p=0.250$. Hence null hypotheses is not accepted. Hence it is interpreted that there positive relationship between market orientation and perception and presence of intensity of competition. Perception of competition as a threat $\left(\mathrm{H}_{0} 6\right)$ and its relationship with Market orientation is discussed here. The result does not support the hypothesized relationship between $\mathrm{H}_{0} 6$ and Perception of competition as a threat ( $p=0.717$ respectively). Thus the null hypothesis is not accepted here. Here alternative hypotheses is accepted and is inferred that there is positive relationship between perception of competition as a threat. It is interpreted that market orientation is triggered by perceiving competition as a threat to long term and short term prosperity of an organization. And taking action before any damage is caused by the competition to the firm. 
Now explained is hypothesized relationship between Perceptions of demand faced by the organization as under or over the capacity to serve $\left(\mathrm{H}_{0} 7\right)$ and market orientation of an organization. The results $(p=.707)$ displayed in table no. 4 don't support the hypothesis and null hypothesis is not accepted. Hence alternative hypothesis is accepted. Establishing positive relationship between market orientation and Perception of demand faced by the organization as under or over the capacity to serve. It market orientation is affected by the firms perception about the demand and are they able to fulfill the demand or still are under serving.

It can be concluded from the above inferences from Table. 3 that except education of senior management $\left(\mathrm{H}_{0} 2\right)$ and Operational entrepreneurship $\left(\mathrm{H}_{0} 4\right)$ are not accepted hence indicating professional commitment, Ethics, perception, competition and capacity to serve (Under/over) are positively related to market orientation.

Table 4: Regression Results Coefficients $^{\mathrm{a}}$

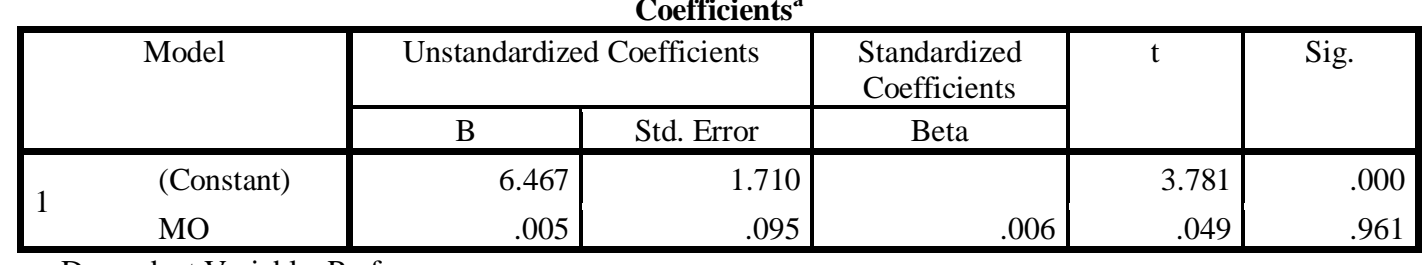

a. Dependent Variable: Performance

The proposed link between market orientation and organizational performance is reflected in $\mathrm{H}_{0} 8$. The results in Table. $4(p=.0961)$ and is not supporting the statement. Hence null hypothesis is not accepted. The alternative hypothesis is accepted and is inferred that there is positive relationship between market orientation and organizational performance. This finding is consistent with the results of previous studies (Jaworski and Kohli 1993; Narver and Slater, 1990; Slater and Narver, 1994; Woods and Bhuian, 2000).

\section{Conclusions and Implications}

This study plays a significant role in validating the relationship between market orientation and performance of tourism and travel industry. These results indicate that senior management's efforts to increase overall operational efficiency possibly could lie in focused efforts develop and adopt market orientation. Market orientation can be achieved through paying extra attention towards development of professional commitment and ethics. The Perception of the presence and intensity of competition, Perception of competition as a threat and Perception of demand as under or over the capacity to serve also serve as key factors achieving organization wide market orientation.

The research marks the different variables determining market orientation also suggesting manager the approaches to enhance market orientation and organizational performance of an organization. The findings suggest that management should find out factors influencing professional education of senior management team pursuing higher organizational performance. The management of an organization should also find out factors affecting operational entrepreneurship of senior management team of an organization. It could again lead organization to achieve higher organizational performance. It is inferred from the findings that organizations should encourage education and sense of entrepreneurship among its senior management team by rewarding their efforts.

\section{Limitations and Areas for further research}

Results of this study suggest the areas for further research. Firstly, examining measure of organizational performance. Also, evaluating the strength of the relationship between market orientations and organizational performance. The future studies should incorporate other measures of organizational performance such as, customer retention, market share, growth in sales and return on investment. As performance measures keep on changing from industry to industry. Efforts to determine and evaluate the role of other factors in determining the level of market orientation should continue. Three environmental factors also were having an effect on market orientation and organizational performance unlike studies in the past (Jaworski and Kohli, 1993; Slater and Narver, 1994, Woods and Bhuian, 2000).

To conclude, this study is restricted by its sample size and cross-sectional focus, which proposes additional factors to considered in future researches. About the sample used in this research, it is limited by its homogeneity. Even though it is desirable to use a homogeneous sample for early theory development and testing (Calder, Phillips, and Tybout, 1981), the further studies should include samples of different stakeholders of tourism and travel industry. In regards with the study's cross-sectional focus, the influence of market orientation on organizational performance in this study has been primarily restricted to association (i.e., probable causal relationships are not tested). The phenomenon of important and covering indicators, where operating results 
which are witnessed during one quarter may be attributed to actions implemented much earlier in time and even by different management, needs further study. With deference to these suggestions, the present study concludes with one important statement: Market-oriented organizations tend to have higher performance than nonmarketoriented organizations. Practitioners and academic researchers, alike, should not overlook this significant finding.

\section{References}

[1]. Aaker, D. A. (2008). Strategic market management. John Wiley \& Sons.

[2]. Ansoff, I. H. (1984). "Implanting Strategic Management", Prentice-Hall, Up-per Saddle River, NJ.

[3]. Bartol, K.M. (1979) "Professionalism as a Prediction of Organizational Commitment, Role Stress, and Turnover: A Multidimensional Approach" Academy of Management Journal 22, pp. 815-821.

[4]. Bhuian, Shahid N "Market Orientation and Successful Not-for-Profit Marketing: Direct Relationships and the Influence of Professional- ism, Entrepreneurship, Competition, and Demand", Unpublished doctoral dissertation, Texas Polytechnic Institute. 1992..

[5]. Bigné, J. E., Andreu, L., Küster, I., \& Blesa, A. (2005). Quality market orientation: tourist agencies' perceived effects. Annals of Tourism Research, 32(4), 1022-1038.

[6]. Burgleman, R. A, (1984), "Designs for Corporate Entrepreneurship in Established Firms.", California Management Review 26(3), pp: 154-66.

[7]. Byrne, J A (1990), "Profiting from the Nonprofits-Much Can Be Learned from Some of the Best-Run Organizations Around", Business Week 26, pp. 66-74.

[8]. Calder B, Phillip L, and Tybout A, (1981), "Designing Research for Application”, Journal of Consumer Research 8, pp. 197-207.

[9]. Carbone R (1990), "Is Fundraising a Profession? Not Yet. Nonprofit World", 8(1), pp. 30-32.

[10]. Covin, J. G., \&Slevin, D. P. (1991) “A conceptual model of entrepreneurship as firm behavior." Entrepreneurship Theory and Practice, pp. $7-25$

[11]. Deshpandé, R., \& Farley, J. U. (1998). Measuring market orientation: generalization and synthesis. Journal of Market-Focused Management, 2(3), 213-232.

[12]. Deshpande, R., \& Webster Jr, F. E. (1989). Organizational culture and marketing: defining the research agenda. The Journal of Marketing, 3-15.

[13]. Drucker, Peter F (1980) Managing in Turbulent Times, Harper and Row, New York.

[14]. Drucker, Peter F (1985)Innovation and Entrepreneurship, Harper and Row, New York.

[15]. Drucker, Peter F (1989), "What Business Can Learn from Non-profits”, Havard Business Review, pp. 88-93.

[16]. Graham, N O, (1990), "Quality Assurance in Hospitals Strategies for Assessment and Implementation", Aspen, Gaithersburg, MD.

[17]. Hambrick, D C, et al. (1989), "Preparing Today’s Leaders for Tomorrow's Realities", Personnel 66(8), pp. 22-26.

[18]. Hambrick, D. C. (1987), “The Top Management Team: Key to Strategic Success", California Management Review 30(1), pp. 88108.

[19]. Han J, Kim N and Srivastava R (1996), "Market orientation and organizational performance: an innovation a missing link" Series No. MKTG 96.084.

[20]. Harmancioglu, N., Grinstein, A. and Goldman, A., (2010) "Innovation and performance outcomes of market information collection efforts: The role of top management team involvement." International Journal of Research in Marketing, Iss. 27, pp. 33-43.

[21]. Jaworski, B J., and Kohli, A K, (1993), “Market Orientation: Antecedents and Consequences.”,Journal of Marketing 57, pp. 53-70.

[22]. Kindra, G S., and Taylor, D. W, (1995), "Demarketing Inappropriate Health Care Consumption. Journal of Health Care Marketing 15(2), pp. 10-14.

[23]. Kohli, A K, and Jaworski, B J (1990), “ Marketing Orientation: The Construct, Research Proposition, and Managerial Implication" Journal of Marketing 54, pp. 1-18.

[24]. Kohli, A K., Jaworski, B J., and Kumar, A, (1993), "MARKOR: A Measure of Market Orientation. Journal of Marketing Research 3o, pp. 467-477.

[25]. Kotler P, (1984) Marketing Management: Analysis, Planning, and Control. Prentice-Hall, Upper Saddle River, NJ.

[26]. Kotler, P (1988), Marketing Management, Prentice-Hall, Upper Saddle River, NJ.

[27]. Kotler, P and Andreasen, A R, (1991), “Strategic Marketing for Non-profit Organizations”. Prentice-Hall, Upper Saddle River, NJ.

[28]. Levitt, Theodore (1969), The Marketing Mode, McGraw Hill, New York.

[29]. Lewrick M, Omar M and William jr R. L (2011), "Market Orientation and Innovators' Success: an Exploration of the Influence of Customer and Competitor Orientation." J. Technol. Management and Innovation, Volume 6, Issue 3, pp. 48-52.

[30]. Lipp, M R (1991), Medical Landmarks USA: A Travel Guide, McGraw-Hill, New York.

[31]. Liu S.S, Luo X, Shi Y (2002), "Integrating customer orientation, corporate entrepreneurship, and learning orientation in organizations-in-transition: an empirical study", Intern. J. of Research in Marketing 19, pp. 376-382.

[32]. Liu, S. S., Dubinsky, A. J., \& Shi, Y. (2000), "Change to survive: China's new state-owned enterprise.” Global Focus: An International Journal of Business, Economics, and Social Policy, 12(2), pp. 87-97.

[33]. Morris, H., \& Paul, G. W. (1987), "The relationship between entrepreneurship and marketing in established firms." Journal of Business Venturing, 2, pp. 247-259.

[34]. Narver J C, and Slater, S F, (1990) "The Effect of a Market Orientation on Business Profitability" Journal of Marketing 54, pp. 2035.

[35]. Nunnally, J. C. (1978). Psychometric Theory. New York: McGraw-Hill Publishing.

[36]. Nunnally, J. C. (1988). Psychometric Theory. New Jersey: McGraw-Hill, Englewood Cliffs.

[37]. Opeda F and Jaiyeoba O, (2011), "Market Orientation: Journey from Antecedents to Business Performance in a Developing Economy: A Case-Study of Botswana's Small and Medium Size Manufacturing Firms", International Journal of Business Administration, Vol. 2, No. 4, pp. 61-68.

[38]. Qu, R., Ennew, C., \& Thea Sinclair, M. (2005). The impact of regulation and ownership structure on market orientation in the tourism industry in China. Tourism Management, 26(6), 939-950.

[39]. Schwartz K (1989) "Nonprofits’ Bottom Line; They Mix Lofty Goals and Gutsy Survival Strategies", Marketing News 23(4), pp. $1-2$.

[40]. Shapero, A (1975), “The Displaced, Uncomfortable Entrepreneur.”, Psychology Today 11(7), pp. 83-89. 
[41]. Siguaw J A, Brown G, and Widing, R E (1994) "The Influence of the Market Orientation of the Firm on Sales Force Behavior and Attribute.” Journal of Marketing Research 31, pp. 106-116.

[42]. Slater, S F, and Narver, J C (1994) “Does Competitive Environment Moderate the Market Orientation Performance Relationship?" Journal of Marketing 58, pp. 46-55.

[43]. Soreze, F., \& Bunić, Ž. Influence of Market Orientation on Business Performance Case: Croatian Manufacturing Companies.

[44]. Unterman I, and Davis R H (1984), "Strategic Management of Not-for-Profit Organizations" Praeger, New York.

[45]. Wang X, Chen K, Zhang Y (2011), "Influences of Market orientation on Business Performance of Express Service Enterprise under mediating effect of Organizational Innovation", Journal of Chinese Marketing, Vol.4 No.1, pp. 35-42.

[46]. Webster, F E (1988) "Rediscovering the Marketing Concept.) Business Horizons 31, pp. 29-39.

[47]. Wood V R., and Bhuian, S N, (1993), "Market Orientation and Nonprofit Organizations: Performance Associations and Research Propositions." Journal of Nonprofit \& Public Sector Marketing 1(1), pp. 7-32.

[48]. Zhou K Z, Brown J R, and Dev C, (2009), "Market orientation, competitive advantage, and performance: A demand-based perspective", Journal of Business Research 62, pp. 1063-1070. 